\title{
USING A MEDIATOR SYSTEM TO INCREASE THE DELIGNIFICATION OF SUGARCANE RESIDUES WITH FUNGAL ENZYMES
}

\author{
USO DE UN SISTEMA MEDIADOR PARA INCREMENTAR LA \\ DESLIGNIFICACIÓN DE RESIDUOS DE CAÑA DE AZÚCAR CON ENZIMAS \\ FÚNGICAS
}

\author{
USO DE UM SISTEMA MEDIADOR PARA INCREMENTAR A DESLIGNIFICAÇÃO DE \\ RESÍDUOS DE CANA DE AÇÚCAR COM ENZIMAS FÚNGICAS
}

Luz-Marina Flórez-Pardo ${ }^{1 *}$, Angela-Sofía Parra-Paz², Jorge-Enrique López-Galán² and Jersson-Ivan Figueroa-Oviedo ${ }^{2}$

'Departamento de Energética y Mecánica, Universidad Autónoma de Occidente, Cali, Valle del Cauca, Colombia ²Escuela de Ingeniería Química, Universidad del Valle, Cali, Valle del Cauca, Colombia

e-mail: Imflorez@uao.edu.co

(Received: Mar. 24, 2015; Accepted: Nov. 04, 2015)

\section{ABSTRACT}

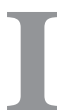

ndustrial residues are resources that generate regional energy security but they have not been sufficiently valued. In southern Colombia, the sugar cane sector produces approximately 9'000000 T/year of residues, mostly represented by tops and leaves. Delignification is a critical step in the process of obtaining ethanol from these residues. The removal of lignin using extracellular enzyme extracts and mediators has not been widely studied. Therefore, a methodology was developed to extract, a cocktail of enzymes consisting of laccase, manganese peroxidase (MnP) and lignoperoxidase (LiP) from Pleurotus ostreatus, which was cultivated by solid substrate fermentation. The extracts with two mediators: 1) ABTS: 2,2'-azino-bis-3ethylbenzthiazoline-6-sulfonic-acid and 2) vanillin, were tested on two different types of residues: untreated residues and pretreated residues with ultrasound. It was found that the crude enzyme extract contained laccase $(0.432 \mathrm{U} / \mathrm{mL})$, LiP $(0.116 \mathrm{U} / \mathrm{mL})$ and $\mathrm{MnP}(0.025 \mathrm{U} / \mathrm{mL})$ activity. Additionally, the results confirmed that this extract was capable of removing $52.7 \%$ of lignin from ultrasound pretreated sugar cane residues and ABTS as the laccase mediator. It is important to highlight that the results obtained were very promising mainly if a more concentrated extracellular extract can be used.

Keywords: Enzymatic delignification, Mediators, Laccase, Pleurotus ostreatus, Lignoperoxidase, Ultrasound pretreatment, Tops and leaves.

How to cite: Flórez-Pardo, L. M., Parra-Paz, A. S., López-Galán, J. E. \& Figueroa-Oviedo, J. I. (2015). Using a mediator system to increase the delignification of sugarcane residues with fungal enzymes. CT\&F - Ciencia, Tecnología y Futuro, 6(2), 81-92.

*To whom correspondence should be addressed 


\title{
RESUMEN
}

\begin{abstract}
- os residuos industriales son recursos que generan una seguridad energética regional, pero ellos no han sido suficientemente valorizados. En el sur de Colombia, el sector de la caña de azúcar produce aproximadamente 9'000 000 T/año de residuos, principalmente representados por hojas y cogollos. De estos residuos es posible obtener etanol y una de las etapas más críticas es su deslignificación. En este proceso, la remoción de lignina con el uso de extractos de enzima extracelular y mediadores, todavía no ha sido ampliamente estudiada. Por consiguiente, se desarrolló una metodología para extraer del hongo Pleurotus ostreatus, el cual fue cultivado por fermentación en substrato sólido, un coctel de enzimas compuesto por lacasa, manganeso peroxidasa (MnP) y lignoperoxidasa (LiP). Estos extractos enzimáticos fueron probados con el uso de dos mediadores: 1) ABTS: 2,2'-azino-bis-3-etilbenzotiazolina-6-ácido sulfonico y 2) vainillina, sobre dos diferentes tipos de residuos: no tratados y pretratados con ultrasonido. Como resultado se encontró que el extracto crudo de enzima estuvo compuesto por actividad lacasa $(0.432 \mathrm{U} / \mathrm{mL})$, LiP $(0.116 \mathrm{U} / \mathrm{mL})$ y $\mathrm{MnP}(0.025 \mathrm{U} / \mathrm{mL})$. Adicionalmente, los resultados confirmaron que este extracto crudo en asocio con ABTS como mediador de lacasa, fue capaz de remover el $52.7 \%$ de la lignina de los residuos de caña de azúcar pretratados con ultrasonido. También es importante resaltar que estos resultados fueron muy promisorios, sobre todo si se puede usar un extracto extracelular más concentrado.
\end{abstract}

Palabras clave: Deslignificación enzimática, Mediadores, Lacasa, Pleurotus ostreatus, Lignoperoxidasa, Tratamiento con ultrasonido, Hojas y cogollos.

\section{RESUMO}

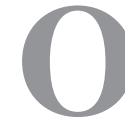

s resíduos industriais são recursos que geram uma segurança energética regional, mas eles não são suficientemente valorizados. No sul da Colômbia, o setor da cana de açúcar produz aproximadamente 9'000 000 T/ano de resíduos, principalmente representados por folhas e miolos. Destes resíduos podemos obter etanol e uma das etapas mais críticas é a deslignificação. Neste processo, a remoção de lignina com o uso de extratos de enzima extracelular e mediadores, ainda não foi amplamente estudada. Consequentemente, foi desenvolvida uma metodologia para a extração do fungo Pleurotus ostreatus, o qual foi cultivado por fermentação em substrato sólido, um coquetel de enzimas composto por lacase, manganês peroxidase (MnP) e lignoperoxidase (LiP). Estes extratos enzimáticos foram testados com o uso dos mediadores: 1) ABTS: 2,2' -azino-bis-3-etilbenzotiazoline-6-ácido sulfônico e 2) vanilina, sobre dois diferentes tipos de resíduos: não tratados e pré-tratados com ultrassom. Como resultado verificou-se que o extrato cru de enzima esteve composto por atividade lacase $(0.432 \mathrm{U} / \mathrm{mL})$, LiP $(0.116 \mathrm{U} / \mathrm{mL})$ e $\mathrm{MnP}$ $(0.025 \mathrm{U} / \mathrm{mL})$. Adicionalmente, os resultados confirmaram que esse extrato cru junto com o ABTS como mediador de lacase foi capaz de remover $52.7 \%$ da lignina dos resíduos de cana de açúcar pré-tratados com ultrassom. Também é importante salientar que estes resultados foram muito promissórios, designadamente, se é possível utilizar um extrato extracelular mais concentrado.

Palavras-chave: Deslignificação enzimática, Mediadores, Lacase, Pleurotus ostreatus, Lignoperoxidase, Tratamento com ultrassom, Folhas e miolos. 


\section{INTRODUCTION}

In the Cauca River geographical (Valle del Cauca, Colombia) region, 205664 hectares of sugar cane are grown annually, resulting in 19 million tons of harvested material. The estimated residues from the harvest are calculated to be approximately 9 million tons (47.37\% of the total cane weight), consisting mainly of tops and leaves (Cenicaña, 2010), affecting cane regrowth and harvest labor activities such as fertilization and irrigation, but providing a significant amount of organic matter to the soil. Burning is an alternative to this problem, but it causes a negative environmental impact. In addition, the potential of these materials as an important source of lignocellulose and other compounds is not taken into account under the bio-refinery concept. The residues contain an average of $39.8 \%$ cellulose, $28.6 \%$ hemicellulose, $22.5 \%$ lignin and $2.4 \%$ ash (Oliveira et al., 2013).

The holocellulose (hemicellulose-cellulose) may be used in the production of second-generation ethanol after pretreatment to remove lignin. Among the physical, chemical and biological pretreatments, alkaline etching resulted in the least furan formation and sugar degradation. Ultrasound is a simpler and faster pretreatment method (Filson \& Dawson-Andoh, 2009; Sun \& Tomkinson, 2002), as compared to the conventional fractionation techniques (Sun et al., 2004). Cavitation by ultrasound generates high temperature, pressure and extreme shear forces (Velmurugan \& Muthukumar, 2012), which improve the lignocellulosic material susceptibility to hydrolysis, most likely because it increases the transport of water or its free radicals to the crystalline cellulose (Benazzi et al., 2013), in such a way that the bonds between lignin and xylan networks are broken (Yaldagard, Mortazavi \& Tabatabaie, 2008).

The white-rot fungi (hundred od Basidiomycetes species) are important for delignification because they degrade lignin, cellulose and hemicellulose through their ability to synthesize extracellular enzymes, although the speed, selectivity and degradation rates of each enzyme can vary significantly from one species to another. The essential enzymes that primarily degrade lignin are phenoloxidases (laccases, EC 1.10.3.2), manganese peroxidase (MnP, EC 1.11.1.13) and lignin peroxidase (LiP, EC 1.11.1.14) (Elisashvili \& Kachlishvili, 2009).
One of the most widely studied basidiomycetes and laccase-producing organisms is Pleurotus ostreatus (Karp et al., 2012). The ability of this microorganism to utilize different lignocellulosic residues is valuable, and the use of its oxidative enzymes is currently important. This fungus is unique because it can produce a complex of three extracellular enzymes. These basidiomycete enzymes are vital for the efficient bioconversion of agro industrial residues, and they are of interest for various biotechnological applications in several industries, such as textile, pulp and paper, food, and cosmetics (Elisashvili \& Kachlishvili, 2009). These enzymes also play an important role in the synthesis of chitin and melanin (a pigment), the resistance of spores, and pathogenesis (Cañas \& Camarero, 2010).

The advantage of enzymatic techniques over chemicals is that the latter are not selective and, in addition to the fermentable sugars obtained, chemical side reactions may generate compounds that inhibit subsequent fermentation. Therefore, it is important to develop strategies that promote more efficient production of these enzymes. Laccase was one of the first enzymes reported because it oxidizes dozens of different compounds (phenols, polyphenols, benzenothiols, polyamines, hydroxyindols, aryl diamines, $\mathrm{Mn}^{2+}, \mathrm{Fe}(\mathrm{EDTA})_{2}$ ) (Maté et al., 2010) and phenolic sub-structures of lignin by one-electron abstraction, producing radicals that can subsequently polymerize or depolymerize (Bourbonnais \& Paice, 1992).

An alternative enzymatic method involves adding mediators (low-molecular-weight molecules capable of intervening in redox reactions), being the laccasemediator system one of the most promising methods (Morozova et al., 2007). In addition to the high redox potential of laccase enzymes, mediators can oxidize phenolic lignin structures and extend the action to nonphenolic structures (Bajpai, 2004). The laccase needs a mediator mainly because of its molecular size, 60-100 kDa (Flickinger \& Drew, 1999), which prevents it from entering into the secondary cell wall (this wall is where most of the free phenolic groups are located); therefore, only superficial fibers are modified in the absence of a mediator (Garcia-Ubasart, 2011). Bourbonnais and Paice (1992) discovered the first compound capable of extending the oxidative action of laccases, which were isolated from the fungus Trametes versicolor, in non- 
phenolic compounds. The compound is 2,2'-azino-bis (3-ethylbenzothiazoline-6-sulfonic acid): ABTS, which is capable of being oxidized by the enzyme and, in turn, can oxidize lignin structures. However, the use of natural mediators may offer economic and environmental benefits. This laccase-mediator system in biofuel production has not been comprehensively reviewed in recent articles (Kudanga \& Le Roes-Hill, 2014) and the high cost associated with enzyme production requires investigation about enzyme extraction and purification methods and the identification of low-cost mediators with reduced toxicity and industrial possibilities. Therefore, the aim of this investigation was to produce an enzyme extract obtained by solid state fermentation of Pleurotus ostreatus and use it for delignification of sugar cane residues using two mediators: vanillin and ABTS. The effect of physical pre-treatment with ultrasound in an alkaline medium on enzymatic delignification was also investigated.

\section{MATERIALS AND METHODS}

\section{Raw Material}

The residues used for the delignification process (sugar cane leaves and tops) were obtained by green harvesting of the sugar cane variety CC 8592 (CC: Cenicaña Colombia, one of the most abundant in the region) with 13.5 months of cultivation age and collected near one of the mills located in the Cauca River valley (Colombia). The samples were mechanically homogenized, washed with distilled water at $40^{\circ} \mathrm{C}$ to remove dirt and impurities and dried in an oven at $60^{\circ} \mathrm{C}$ until constant weight. Afterwards, they were milled and sieved to a size between 0.25 and $0.42 \mathrm{~mm}$ (Velmurugan \& Muthukumar, 2012). The composition of the residues used in the present study was characterized.

\section{Analytical Methods}

Extractives were determined according to NREL methodology (Sluiter, 2008). Cellulose, hemicellulose, and ash were determined by the Van Soest gravimetric method (Van Soest, Robertson \& Lewis, 1991) and The Klason extraction method was used to extract lignin (Sluiter et al., 2011). All the assays and analysis were made in triplicate.

\section{Extracellular Enzyme Extract Preparation}

\section{Solid-state Fermentation}

Fermentation was performed in $300 \mathrm{~mL}$ bottles into which a cylindrical device made of porous and inert to solvents polymeric material was introduced to ensure an increased interfacial area that led to fungal growth. A 20 g solid substrate sample, containing 50\% sawdust and $50 \%$ soybean hulls, was added to each container device to provide a source of nitrogen. The sawdust and soybean hulls had previously been washed, dried at $40^{\circ} \mathrm{C}$, milled and sieved (size particle between mesh $-10+20$ ). This substrate was then moistened with water for 12 hours up to a final weight of $50 \mathrm{~g}$. The entire substrate was autoclaved at $120^{\circ} \mathrm{C}$ for one hour. The inoculum corresponded to a commercial strain of Pleurotus ostreatus taken from the collection placed in the Universidad Autónoma de Occidente (Colombia), which was reactivated in $10 \mathrm{~cm}$-diameter Petri dishes containing 3\% Sabouraud agar medium. After 8 days of incubation, three $0.5 \mathrm{~cm}$-diameter pieces of each Petri dish were taken with an inoculation loop and placed at a depth of $3 \mathrm{~cm}$ in each container. The containers were then covered with sterile cotton. All sowings were made the same day for one hour to ensure homogenous mycelium growth and consistent enzyme production. The samples were incubated at a constant temperature of $28^{\circ} \mathrm{C}$ during 30 days.

\section{Enzymes Extraction}

The enzymes produced during solid-state fermentation were extracted using $50 \mathrm{mM}$ sodium acetate buffer $(\mathrm{pH}$ 4.8) at temperature between 4 and $5^{\circ} \mathrm{C}$ and a ratio of $2 \mathrm{~mL} / \mathrm{g}$ of substrate during 4 hours. Then, the solution was vacuum filtered and the filtrate was centrifuged at $11000 \mathrm{rpm}$ during 30 minutes. The clarified supernatant or "extracellular enzyme extract" was stored in an amber container at $-2^{\circ} \mathrm{C}$ for later analysis. The enzyme extract was obtained at $10,15,20$, and 30 days of fungal growth.

\section{Enzyme Extract Characterization}

The method described by Lowry et al. (1951) and Hartree (1972) was used to quantify the protein content in the enzyme extract using bovine serum albumin as a standard. Laccase activity was measured by ABTS oxidation at $30^{\circ} \mathrm{C}$. The increase in absorbance at 420 nm was measured on a Hach 2010 Spectrophotometer using $1 \mathrm{~mL}$ of sample, composed of $880 \mu \mathrm{L}$ of $100 \mathrm{mM}$ sodium acetate buffer, $\mathrm{pH} 5.0,100 \mu \mathrm{L}$ of ABTS (final concentration $1 \mathrm{mM}$ ), and $20 \mu \mathrm{L}$ of enzyme extract. The laccase activity was measured in International Units (IU), which was defined as the amount of enzyme that is needed to produce $1 \mu \mathrm{mol}$ of oxidized ABTS/ 
min (Jeon, 2008). A modified methodology based on that described by Fujii et al. (2013) was followed to quantify the activity of manganese peroxidase (MnP) and lignin peroxidase (LiP). To measure MnP activity, the following substances were placed into a cuvette in successive order: a) $600 \mu \mathrm{L}$ of $0.3 \mathrm{mM}$ sodium tartrate buffer at pH 5, b) $100 \mu \mathrm{L}$ of $1 \mathrm{mM} \mathrm{MnSO}_{4}$, which acts as a cofactor, c) $100 \mu \mathrm{L}$ of $1 \mathrm{mM}$ acetone vanillin solution, d) $50 \mu \mathrm{L}$ of extracellular enzyme extract and e) $50 \mu \mathrm{L}$ of a $1 \% \mathrm{H}_{2} \mathrm{O}_{2}$ solution. The change in absorbance was measured at $334 \mathrm{~nm}$ from 0 to 5 minutes and compared to a blank consisting of the same mixture without the extracellular enzyme extract to be assessed. A plot of absorbance vs. time should exhibit a negative slope. Similarly for LiP, the following were placed into a cuvette: a) $700 \mu \mathrm{L}$ of a $0.15 \mathrm{M}$ sodium tartrate buffer at $\mathrm{pH} 3$, b) $50 \mu \mathrm{L}$ of a $10 \mathrm{mM}$ veratryl alcohol solution, c) $100 \mu \mathrm{L}$ of extracellular enzyme extract and d) $50 \mu \mathrm{L}$ of a $1 \% \mathrm{H}_{2} \mathrm{O}_{2}$ solution. The change in absorbance at 310 nm from 0 to 5 minutes compared to the blank (positive slope) was measured. Units of LiP activity are defined as the amount of enzyme required to oxidize $1 \mu \mathrm{mol}$ of veratryl alcohol per minute, and units of $\mathrm{MnP}$ are defined as the amount of enzyme required to oxidize $1 \mu \mathrm{mol}$ of $\mathrm{Mn}^{+2}$ to $\mathrm{Mn}^{+3}$ per minute.

\section{Delignification with Extracellular Enzymatic Extract and Mediator \\ Pretreatment of Sugar Cane Residues with Ultrasound}

Five grams of sugar cane residue mixture (leaves and tops) with moisture of $3.9 \% \mathrm{w} / \mathrm{w}$ and a particle size of $0.25 \mathrm{~mm}$ were placed in an Erlenmeyer flask. Then, 100 $\mathrm{mL}$ of a solution of $1 \% \mathrm{NaOH}$ was added to the solid, and the suspension was stirred until it became uniform at $25^{\circ} \mathrm{C}$. Subsequently, the sample was treated using an Ultrasonic Processor (model GE 130) according to $2^{2}$ factorial designs, two different intensities (40 and 80\% of its maximum power of $130 \mathrm{~W}$ ) and two different pulse times (1.5 and $10 \mathrm{~s}$ ) during four minutes with no further stirring. The frequency was maintained at $20 \mathrm{KHz}$. The sample was removed from the container and dried at 50 ${ }^{\circ} \mathrm{C}$ until a constant weight was achieved, and the residual lignin was determined by the Kappa method (TAPPI, 1999). The treated residue was used for subsequent delignification with extracellular enzyme extract.

\section{Enzymatic Delignification with Extracellular Extract}

The equivalent of $2 \mathrm{~g}$ of pre-treated sugar cane residue was weighed in $250 \mathrm{~mL}$ Erlenmeyer flask. The required volume of extracellular enzyme extract was added (without purification or concentration): 50, 100 and $150 \mathrm{~mL}$ extracellular enzyme extract/g pretreated residues. Following the treatment, the mediator was added (vanillin in the ratio of $5 \mathrm{mg} / \mathrm{g}$ dry fiber or 1 $\mathrm{mM} / \mathrm{g}$ dry fiber in the case of ABTS). The $\mathrm{pH}$ was adjusted to 4.8 by adding a $50 \mathrm{mM}$ acetate buffer to a final dry solid concentration of $10 \%(\mathrm{w} / \mathrm{v})$ (Bourbonnais et al., 1997). The vessel was stirred in a Shellab orbital shaker at $200 \mathrm{rpm}$ and $40^{\circ} \mathrm{C}$ (Bourbonnais \& Paice, $1992)$ for the time required by each treatment $(1,2$, and $3 \mathrm{~h}$ ). After this process, the remaining solids were filtered, washed and dried at $60^{\circ} \mathrm{C}$ until a constant weight was achieved. Later, the Kappa number was measured. The same procedure was replicated with a sample of non-pretreated residues, using vanillin or ABTS as the mediator (control sample).

The influences of the enzyme/substrate $(\mathrm{E} / \mathrm{S}, \mathrm{mL}$ enzyme/g substrate) ratio and time were also evaluated on the delignification process with vanillin as a mediator and pretreated material. For this purpose, a central composite rotatable design was used at random. In this design, the lower level of the E/S was $1 / 10$, and the upper level was $1 / 1$. In terms of time, 1 and $24 \mathrm{~h}$ represented the lower and upper time limits, respectively. The tests were performed by triplicate, and the average value was determined. Variables with a confidence level higher than $95 \%$ were taken as significant in the delignification process. The analysis of variance (ANOVA) and response surface methodology was performed using the Statgraphics ${ }^{\circledR}$ Centurion XV software.

\section{RESULTS AND DISCUSSION}

\section{Residues Characterization}

The chemical composition of sugar cane residues was as follows: extractives $4.7 \% \pm 0.02$, cellulose $39.8 \% \pm$ 1.4 , hemicellulose $32.4 \% \pm 0.8$, lignin $21.2 \% \pm 0.04$ and ash $1.1 \% \pm 0.01$. These results match the range reported for different samples of sugar cane bagasse and straws as noted by Szczerbowski et al. (2014).

\section{Effect of Ultrasound Pretreatment on Lignin Composition}

According to the variance analysis results, the two studied effects were significant $(\alpha<0.05)$ for 
ultrasound delignification, as demonstrated by the Pareto chart in Figure 1. However, it should be noted that the vibration intensity had a greater effect on the reduction of the Kappa number than the frequency at which the pulse occurred. Similarly, Benazzi et al. (2013) found that increasing the ultrasound power (93 to $154 \mathrm{~W}$ ) increased the susceptibility of sugarcane bagasse for later enzymatic hydrolysis. This is probably due to the increased power intensity of the ultrasound producing greater wave pressure through the surface of lignocellulosic material, which causes cavitation bubbles to implode. The resulting increase in microfractures (Benazzi et al., 2013; Peng et al., 2012) opens the solid substrate surface or causes swelling of the cell wall to facilitate lignin solubility in the alkaline medium and the subsequent action of the enzymes (Yachmenev et al., 2009).

The highest reduction in lignin (24.7\%, from 59.9 to the Kappa number in untreated residues) was achieved using the lowest pulse (1 second) and the maximum intensity (80\%), as observed in the contour plot of Figure 1. This graph followed a second order model with an $\mathrm{r}^{2}$ of $99.7 \%$ and a standard deviation of 0.05 . Although the direct aim of this kind of pretreatment was not lignin removal, some previous studies on sugarcane leaves and tops residues showed that a certain degree of delignification is necessary to expose the fiber and allow the action of laccase (Salcedo, López \& Flórez, 2011). It was also found that the highest delignification level was achieved in 4 minutes under the best conditions. The conditions used in this study were less severe than those applied on bagasse by Velmurugan and Muthukumar (2012), where temperature of $70.15^{\circ} \mathrm{C}$, sonification time of $47.42 \mathrm{~min}, \mathrm{NaOH}$ concentration of $2.89 \%$, and power of $400 \mathrm{~W}$ were necessary to obtain a $96.27 \%$ yield of reducing sugars after enzymatic hydrolysis.

\section{Enzymatic Delignification}

\section{Enzymes Production}

The system designed for solid-state fermentation (Figure 2b) allowed for an easy removal of the substrate without generating the losses observed for the first system designed (Figure 2a). It also favored more uniform transfer of oxygen and facilitated enzyme extraction (Rodríguez Couto \& Sanromán, 2005).

During the 30 days of mycelium growth, it was observed that the highest concentration of protein, $6 \mathrm{~g} / \mathrm{L}$, was obtained at day 15 . For this reason, the extracellular enzyme extract was recovered at this point. This result is consistent with previous studies in which the largest amount of ligninolytic enzymes was expressed between 15 and 20 days of solid state fermentation using banana residual waste as a substrate with two different species of Pleurotus (Reddy et al., 2003). However, these results are different from those observed with other fungi such as Ganoderma lucidum 246 and Cerrena unicolor 300, which express the highest amount of laccase after 10 days of submerged fermentation on mandarin peelings (Elisashvili \& Kachlishvili, 2009) or after 5 days of solid-state fermentation with $\mathrm{CuSO}_{4}$ and ferulic acid as the inducer of laccase activity with $P$. ostreatus strain 22 Em (Karp et al., 2012).

Laccase enzyme activity was $0.432 \mathrm{IU} / \mathrm{mL}$ at the end of the process. This activity was higher to that reported by Piscitelli et al. (2005) who expressed laccases extracted of Pleurotus ostreatus in Kluyveromyces lactis (0.2 IU/

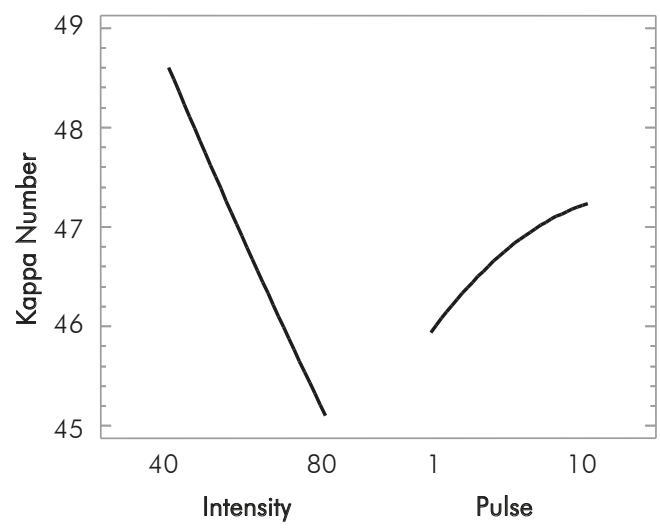

(a)

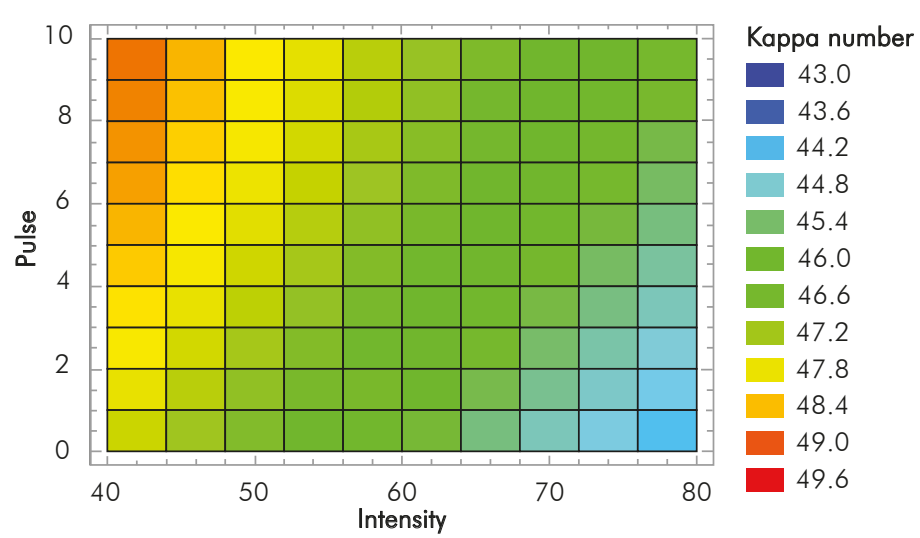

(b)

Figure 1. (a) Main effects plot for ultrasound pretreatment vs Kappa function. (b) contour plot (Statgraphics ${ }^{\circledR}$ Centurion XV software). 


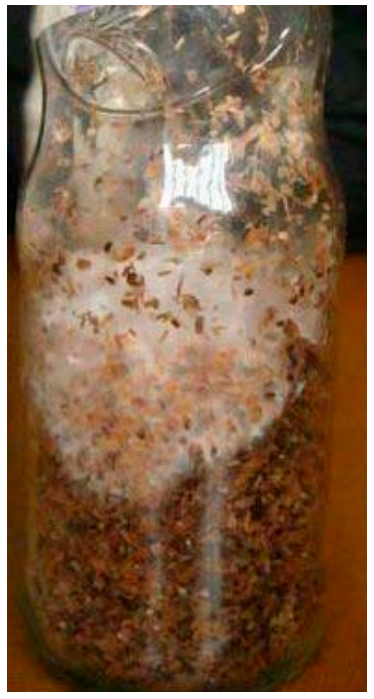

(a)

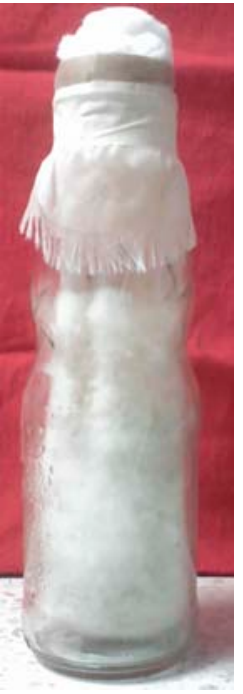

(b)
Figure 2. Growth of Pleurotus ostreatus in solid-state fermentation: (a) Without internal device. (b) With internal cylindrical device.

$\mathrm{mL}$ ) but lower than the $10 \mathrm{IU} / \mathrm{mL}$ concentration found by Liu et al. (2009) using the same type of fungal during 20 days. This amount is greater because the extract was subjected to various concentration processes, which were not carried out in the present study. Additionally they used an inducer which improved the expression of the laccase activity. Therefore, it is valid to say, as observed by Elisashvili and Kachlishvili (2009), that laccase concentration depends not only on the type of inducer used but also on the type of lignocellulosic substrate, the carbon source, the addition of aromatic compounds, the type of microorganism (Cerrena and Ganoderma lucidum are good laccase producers), and the practice of co-cultivation. Thus, laccase concentrations can range from $0.5 \mathrm{IU} / \mathrm{mL}$ to $75 \mathrm{IU} / \mathrm{mL}$. So, in this research, enzymatic activities of $0.116 \mathrm{IU} / \mathrm{mL}$ and $0.025 \mathrm{IU} / \mathrm{mL}$ for $\mathrm{LiP}$ and MnP, respectively, were also observed, demonstrating the ability of Pleurotus ostreatus to produce these enzymes, since there are only a few microorganisms that can secrete LiP and $\mathrm{MnP}$ in extracellular form. The mechanism used by these enzymes to act synergistically with laccase is not fully understood (Fujian, Hongzhang \& Zuohu, 2001).

\section{Delignification with Extracellular Enzyme Extract and Mediator}

Compounds such as vanillin, acetovanillone, methyl vanillate, syringaldehyde, and p-coumaric acid have emerged as alternatives to the use of synthetic laccasemediator systems (Camarero et al., 2005; Cañas et al., 2007). According to the results, the ultrasound pretreatment is necessary to increase the amount of lignin removed from sugar cane crop residues. When using the enzymatic cocktail on untreated residues, the maximum amount of lignin removed was only of $15 \%$, in relation to the initial Kappa number (Table 1 ). The results of delignification using vanillin as mediator show that pretreatment increases the yield of delignified residues by $51.3 \%$ (from $15.2 \%$ to $23.0 \%$ ) when the higher dose of enzyme is used for a 3-h period of time. It is possible that ultrasound waves produced

Table 1. Delignification Percentages with ABTS and Vanillin as Mediators.

\begin{tabular}{|c|c|c|c|c|c|c|}
\hline & & & & \multicolumn{3}{|c|}{ UNTREATED } \\
\hline & & & & & illin (medic & \\
\hline & & \multicolumn{2}{|c|}{ Enzyme doses $(\mathrm{mL})$} & $1 \mathrm{~h}$ & $2 \mathrm{~h}$ & $3 \mathrm{~h}$ \\
\hline & & \multicolumn{2}{|c|}{1} & $7.5 \pm 0.5$ & $10.5 \pm 0.7$ & $13.2 \pm 0.7$ \\
\hline & & \multicolumn{2}{|c|}{2} & $9.5 \pm 0.7$ & $11.5 \pm 1.0$ & $14.5 \pm 0.8$ \\
\hline & & \multicolumn{2}{|c|}{3} & $9.8 \pm 0.9$ & $12.5 \pm 0.6$ & $15.2 \pm 0.7$ \\
\hline \multicolumn{7}{|c|}{ TREATED (Ultrasound) } \\
\hline & \multicolumn{3}{|c|}{ ABTS (mediator) } & \multicolumn{3}{|c|}{ Vanillin (mediator) } \\
\hline $\begin{array}{l}\text { Enzyme doses } \\
(\mathrm{mL})\end{array}$ & 1h & $2 h$ & $3 h$ & $1 \mathrm{~h}$ & $2 h$ & $3 \mathrm{~h}$ \\
\hline 1 & $19.5 \pm 1.8$ & $23.5 \pm 2.2$ & $25.6 \pm 2.2$ & $14.5 \pm 0.6$ & $18.0 \pm 1.4$ & $21.0 \pm 1.3$ \\
\hline 2 & $20.9 \pm 1.9$ & $24.2 \pm 2.0$ & $26.7 \pm 2.1$ & $17.0 \pm 1.1$ & $19.0 \pm 1.4$ & $22.0 \pm 1.8$ \\
\hline 3 & $21.9 \pm 1.9$ & $25.0 \pm 2.1$ & $27.9 \pm 2.1$ & $17.5 \pm 1.0$ & $19.8 \pm 1.5$ & $23.0 \pm 1.7$ \\
\hline
\end{tabular}

Note: The reported values concern the enzymatic delignification process itself, without considering the percentage of lignin that has been removed by the use of ultrasound as a pretreatment, which amounted to $24.7 \%$. 
microstructures that enabled greater accessibility of ligninolytic enzymes to the substrate, favoring greater lignin extraction.

The ABTS mediator was more likely to react with Pleurotus ostreatus laccase than vanillin; hence that in relation with vanillin, a $21.7 \%$ increase in lignin removal was achieved using this mediator (from 23\% to 28\%, see Table 1). Similar results were reported by Jeon et al. (2008) for the laccase obtained from G. lucidum fungi. The major efficiency of ABTS could be explained by two factors: its higher rate of oxidation or redox potential by laccase and the reactivity of the oxidized ABTS with lignin. (Bourbonnais et al., 1997). This effect of ABTS is due to its size, which allows the mediator to access the cell wall and act on the non-phenolic and phenolic groups found within. The oxygen present in the solution oxidizes the enzyme, which subsequently oxidizes the mediator by taking an electron and generating a free radical. The oxidized mediator then diffuses into the fiber and oxidizes lignin. The next cycle begins when oxygen is reduced to water (Jeon et al., 2008; Fujian et al., 2001; Camarero et al., 2005).

Given the environmentally friendly character of vanillin for possible industrial applications, this compound was studied for its potential effects on E/S and on the time required to achieve results similar to those found with the ABTS. The Pareto diagram (Figure 3) showed that both variables, time and E/S, have a significant effect $(p<0.005)$ on lignin removal from pretreated residues. However, the larger effect on delignification was observed with increased time.

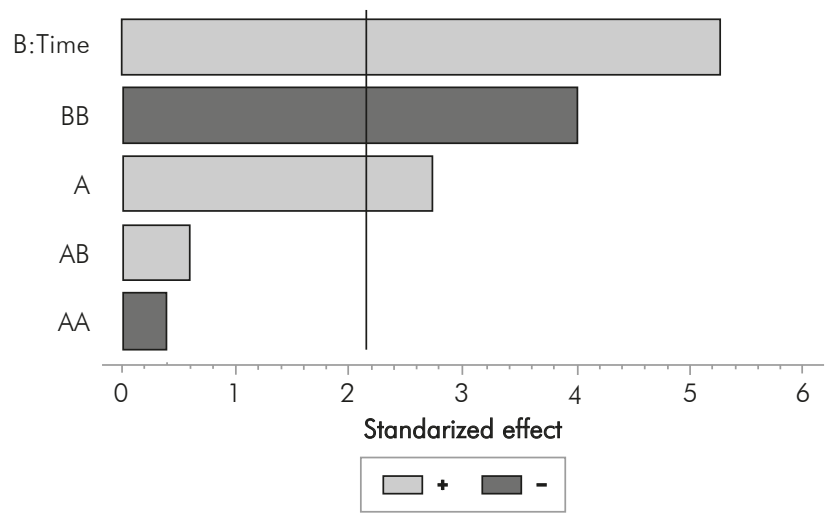

Figure 3. Pareto diagram for lignin removal with vainillin as mediator (Statgraphics ${ }^{\circledR}$ Centurion XV software).
According to the contour plot results, the highest delignification effect with the action of mediator $(32 \%)$ was obtained for an E/S of 1 and 18 h (Figure 4). Otherwise a delignification effect close to that of ABTS (28\%) occurs at $8 \mathrm{~h}$ with an E/S of 0.75 . Further cost/ benefit studies are necessary to elucidate the best option because ABTS has a faster delignification action $(3 \mathrm{~h})$ than vanillin has. The contour plot was obtained from a second order model, showing a $\mathrm{r}^{2}$ correlation coefficient of $99.73 \%$.

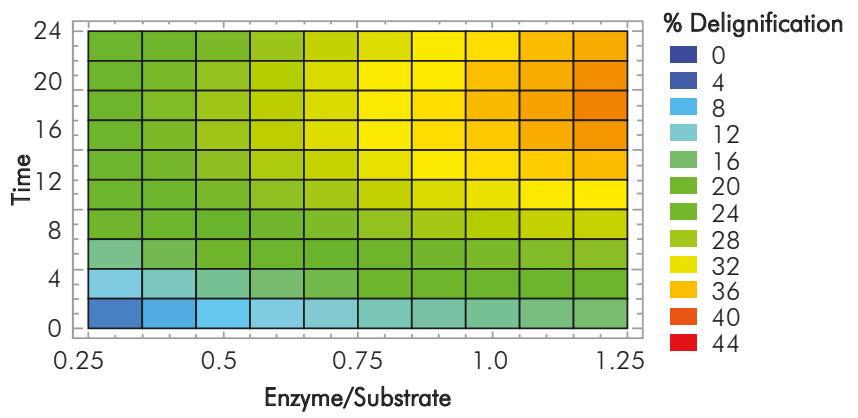

Figure 4. Contour plot for delignification of treated sugar cane residues (Statgraphics ${ }^{\circledR}$ Centurion XV software).

The degree of net residue delignification achieved with this methodology was $52.7 \%$ (sum of the ultrasound in alkaline medium and the enzyme complex-ABTS delignification). The results found in this study are similar to other studies in which chemical methods have been applied to delignify the same type of residue (Salcedo et al., 2011), but using higher temperature $\left(160^{\circ} \mathrm{C}\right)$ compared to the $40^{\circ} \mathrm{C}$ used in enzymatic delignification. However, further efforts should be focused on enhancing the use of vanillin as a mediator because it is more eco-friendly. The delignification time can be reduced, for example, by using purified enzymes, as described by Park and Park (2014). It is also clear that the highest yielding method of delignification is the $\mathrm{NaOH}$ and steam explosion method used in the paper industry (Rocha et al., 2012). Pulp and paper industry mainly uses the kraft process also known as sulfate process, which is known to use a mixture of sodium hydroxide and sodium sulfide (white liquor). The black liquor produced (containing lignin), although it may represent an environmental problem, is used as energy source for the boilers. Furthermore there are several studies dealing with lignin recovery from that black liquor (as already occurs for the recovery of lignin from spent sulphite liquor, i.e., Lignoboost process). 


\section{CONCLUSION}

Pre-treatment with ultrasound in alkaline medium has a higher efficiency when the fiber (sugarcane crop residue) is subjected to an $80 \%$ intensity pulse every 1 second. This treatment results in $24.7 \%$ fiber delignification in 4 min. However the most significant improvement of lignin removal was obtained when ABTS as a mediator was used. The global yield for the delignification process increased to $52.7 \%$ when a crude extracellular extract was used, consisting of a mix of ligninolytic enzymes with laccase $(0.432 \mathrm{IU} / \mathrm{mL})$, LiP (0.116 IU/mL), and MnP (0.025 IU/mL) activity. Further research into the use of ABTS with mixtures of natural mediators, as a way to reduce the time required for delignification with vanillin has to be performed. Also, utilization of concentrated enzyme extracts is recommended to reduce consumption of mediators and obtain higher yields.

\section{ACKNOWLEDGEMENTS}

The authors thank the Universidad Autónoma de Occidente, Universidad del Valle and the Ministry of Agriculture and Rural Development Project 3719-346 2007D-07 of Colombia for funding this project.

\section{REFERENCES}

Bajpai, P. (2004). Biological bleaching of chemical pulps. Crit. Rev. Biotechnol., 24(1), 1-58.

Benazzi, T., Calgaroto, S., Astolfi, V., Rosa, C. D., Oliveira, J. V. \& Mazutti, M. A. (2013). Pretreatment of sugarcane bagasse using supercritical carbon dioxide combined with ultrasound to improve the enzymatic hydrolysis. Enzyme Microb. Technol., 52(4-5), 247-250.

Bourbonnais, R. \& Paice, M. (1992). Demethylation and delignification of kraft pulp by Trametes versicolor laccase in the presence of 2,2'-azinobis-(3-ethylbenzthiazoline-6sulphonate). Appl. Microbiol. Biotechnol., 36(6), 823-827.

Bourbonnais, R., Paice, M., Freiermuth, B., Bodie, E. \& Borneman, S. (1997). Reactivities of various mediators and laccases with Kraft pulp and lignin model compounds. Appl. Environ. Microbiol., 63(12), 4627-4632.

Camarero, S., Ibarra, D., Martínez, M. \& Martínez, A. (2005). Lignin derived compounds as efficient laccase mediators for decolorization of different types of recalcitrant dyes. Appl. Environ. Microbiol., 71(4), 1775-1784.
Cañas, A., Alcalde, M., Plou, F., Martínez, M., Martínez, A. \& Camarero, S. (2007). Transformation of polycyclic aromatic hydrocarbons by lacasse is strongly enhanced by phenolic compounds present in soil. Environ. Sci. Technol., 41(8), 2964-2971.

Cañas, A. \& Camarero, S. (2010). Laccases and their natural mediators: Biotechnological tools for sustainable ecofriendly processes. Biotechnol. Adv., 28(6), 694-705.

Cenicaña. (2010). Boletines diarios de la red meteorológica automatizada-RMA. [Online]. [Accessed: 03-Jun-2014]. Available from: <http://www.cenicana.org/clima_/ boletin_meteoro_diario.php $>$.

Elisashvili, V. \& Kachlishvili, E. (2009). Physiological regulation of laccase and manganese peroxidase production by white-rot Basidiomycetes. J. Biotechnol., 144(1), 37-42.

Filson, P. B. \& Dawson-Andoh, B. E. (2009). Sono-chemical preparation of cellulose nanocrrystals from lignocellulose derived materials. Bioresource Technol., 100(7), 22592264.

Flickinger, M. \& Drew, S. (1999). Encyclopedia of bioprocess technology: Fermentation, biocatalysis and bioseparation. New York: John Wiley and Sons.

Fujian, X., Hongzhang, C. \& Zuohu, L. (2001). Solid state production of lignin peroxidase (LiP) and manganese peroxidase $(\mathrm{MnP})$ by Phanerochaete chrysosporium using steam-exploded straw as substrate. Bioresour. Technol., 80(2), 149-155.

Fujii, K., Uemura, M., Hayakawa, C., Funakawa, S. \& Kosaki, T. (2013). Environmental control of lignin peroxidase, manganese peroxidase, and laccase activities in forest floor layers in humid Asia. Soil Biol. Biochem., 57: 109-115.

Garcia-Ubasart, J., Esteban, A., Vila, C., Roncero, M. B., Colom, J. F. \& Vidal, T. (2011). Enzymatic treatments of pulp using laccase and hydrophobic compounds. Bioresour. Technol., 102(3), 2799-2803.

Hartree, E. F. (1972). Determination of protein: A modification of the Lowry method that gives a linear photometric response. Anal. Biochem., 48(2), 422-427.

Jeon, J. R., Murugesan, K., Kim, Y., Kim, E. \& Chang, Y. (2008). Synergistic effect of laccase mediators on pentachlorophenol removal by Ganoderma lucidum laccase. Appl. Microbiol. Biotechnol., 81(4), 783-790. 
Karp, S. G., Faraco, V., Amore, A., Birolo, L., Giangrande, C., Soccol, V. T., Pandey, A. \& Soccol, C. R. (2012). Characterization of laccase isoforms produced by Pleurotus ostreatus in solid state fermentation of sugarcane bagasse. Bioresour. Technol., 114: 735-739.

Kudanga, T. \& Le Roes-Hill, M. (2014). Laccase applications in biofuels production: Current status and future prospects. Appl. Microbiol. Biotechnol., 98(15), 6525-6542.

Liu, L., Lin, Z., Zheng, T., Lin, L., Zheng, C., Lin, Z., Wang, S. \& Wang, Z. (2009). Fermentation optimization and characterization of the laccase from Pleurotus ostreatus strain 10969. Enzyme Microb. Technol., 44(6-7), 426-433.

Lowry, O. H., Rosebrough, N., Farr, A. L. \& Randall, R. (1951). Protein measurement with the folin phenol reagent. J. Biol. Chem., 193: 265-275.

Maté, D., García-Burgos, C., García-Ruiz, E., Ballesteros, A.O., Camarero, S. \& Alcalde, M. (2010). Laboratory evolution of high-redox potential laccases. Chem. Biol., 17(9), 1030-1041.

Morozova, O. V., Shumakovich, G. P., Shleev, S. V. \& Yaropolov, Y. I. (2007). Laccase-mediator systems and their applications: A review. Appl. Biochem. Microbiol., 43(5), 523-535.

Oliveira, F. M. V., Pinheiro, I. O., Souto-Maior, A. M., Martin, C., Gonçalves, A. R. \& Rocha, G. J. M. (2013). Industrialscale steam explosion pretreatment of sugarcane straw for enzymatic hydrolysis of cellulose for production of second generation ethanol and value-added products. Bioresource Technol., 130: 168-173.

Park, N. \& Park, S. S. (2014). Purification and characterization of a novel laccase from Fomitopsis pinicola mycelia. Int. J. Biol. Macromol., 70: 583-589.

Peng, F., Peng, P., Xu, F. \& Sun, R. C. (2012). Fractional purification and bioconversion of hemicelluloses. Biotechnol. Adv., 30(4), 879-903.

Piscitelli, A., Giardina, P., Mazzoni, C. \& Sannia, G. (2005). Recombinant expression of Pleurotus ostreatus laccases in Kluyveromyces lactis and Saccharomyces cerevisiae. Appl. Microbiol. Biotechnol., 29(4), 428-439.

Reddy, G. V., Ravindra-Babu, P., Komaraiah, P., Roy, K. R. R. M. \& Kothari, L. (2003). Utilization of banana waste for the production of lignolytic and cellulolytic enzymes by solid substrate fermentation using two Pleurotus species
(P. ostreatus and P. sajor-caju). Process Biochem., 38(10), 1457-1462.

Rocha, G. J. M., Gonçalves, A. R., Oliveira, B. R., Olivares, E. G. \& Rossell, C. E. V. (2012). Steam explosion pretreatment reproduction and alkaline delignification reactions performed on a pilot scale with sugarcane bagasse for bioethanol production. Ind. Crop. Prod., 35(1), 274-279.

Rodríguez Couto, S. \& Sanromán, M. (2005). Application of solid-state fermentation to lignolytic enzyme production. Biochem. Eng. J., 22(3), 211-219.

Salcedo, J. G., López, J. E. \& Flórez, L. M. (2011). Evaluación de enzimas para la hidrólisis de residuos (hojas y cogollos) de la cosecha caña de azúcar. DYNA, 78(169), 182-190.

Sluiter, A., Hames, B., Ruiz, R., Scarlata, C., Sluiter, J., Templeton, D. \& Crocker, D. (2011). Determination of structural carbohydrates and lignin in biomass. Technical Report NREL/TP-510-42618. Golden, CO, 18 pp.

Sluiter, A., Ruiz, R., Scarlata, C., Sluiter, J. \& Templeton, D. (2008). Determination of extractives in biomass. Technical Report NREL/TP-510-42619. Golden, CO, 12 pp.

Sun, J. X., Sun, R. C., Sun, X. F. \& Su, Y. Q. (2004). Fractional and physico-chemical characterization of hemicelluloses from ultrasonic irradiated sugarcane bagasse. Carbohydr. Res., 339(2), 291-300.

Sun, R. \& Tomkinson, J. (2002). Comparative study of lignins isolated by alkali and ultrasound-assisted alkali extractions from wheat straw. Ultrason. Sonochem., 9(2), 85-93.

Szczerbowski, D., Pitarelo, A. P., Zandoná Filho, A. \& Pereira Ramos, L. (2014). Sugarcane biomass for biorefineries: Comparative composition of carbohydrate and non-carbohydrate components of bagasse and straw. Carbohydr. Polym., 114: 95-101.

TAPPI. (1999). Technical Association of the Pulp and Paper Industry. Kappa number of pulp. T 236 om-99. Canada, 4p.

Van Soest, P. J., Robertson, J. B. \& Lewis, B. A. (1991). Methods for dietary fiber, neutral detergent fiber and nonstarch polysaccharides in relation to animal nutrition. $J$. Dairy Sci., 74(10), 3583-3597.

Velmurugan, R. \& Muthukumar, K. (2012). Ultrasoundassisted alkaline pretreatment of sugarcane bagasse for fermentable sugar production: Optimization through 
response surface methodology. Bioresource Technol., 112: 293-299.

Yachmenev, V., Condon, B., Klasson, T. \& Lambert, A. (2009). Acceleration of the enzymatic hydrolysis of corn stover and sugar cane bagasse celluloses by low intensity uniform ultrasound. J. Biobased Mater. Bio., 3(1-7), 25-31.

Yaldagard, M., Mortazavi, S. A. \& Tabatabaie, F. (2008). The effect of ultrasound in combination with thermal treatment on the germinated barley's alpha-amylase activity. Korean J. Chem. Eng., 25(3), 517-523.

\section{AUTHORS}

\section{Luz-Marina Flórez-Pardo}

Affiliation: Universidad Autónoma de Occidente

Chemical Engineer, Universidad Industrial de Santander

Ph. D. in Chemical Sciences, Universidad Politécnica de Valencia e-mail:1mflorez@uao.edu.co

\section{Angela-Sofía Parra-Paz}

Affiliation: Universidad del Valle

Chemical Engineer, Universidad del Valle

M. Sc. in Environmental and Sanitary Engineering, Universidad del Valle e-mail: angelasopp@gmail.com

\section{Jorge-Enrique López-Galán}

Affiliation: Universidad del Valle

Chemical Engineer, Universidad Industrial de Santander

Ph. D. in Chemical Sciences, Université d'Orléans

e-mail: jorge.lopez@correounivalle.edu.co

\section{Jersson-Ivan Figueroa-Oviedo}

Affiliation: Universidad del Valle

Chemical Engineer, Universidad del Valle

e-mail: jerssonfigueroa@hotmail.com 
